\title{
The Impact of Various Surfactants on the Water-in-Diesel Fuel Emulsions
}

\author{
Khaleel I Abass \\ (Mechanical Engineering Department, University of Technology, Iraq)
}

\begin{abstract}
Diesel fuel is a hydrocarbon fuel is located at the middle of the hydrocarbon chain resulting in the distillation tower.This fuel is used commonly in the entire world and especially in Iraq for the production of electrical energy, transportation, and factories. Diesel burning produces large exhaust pollutants which are mostly blackcarbon, NOx, and SOx. These contaminants are widely polluting the surrounding environment and mischievous. In this research, a study on the possibility of mixing the diesel fuel with water to produce an emulsion that reduce the resulting exhaust pollutants from it, and improves the produced energy.

This study aims to highlight the impact of using various surfactant agents' types with the formulation of waterin-oil (w/o) emulsions for the Iraqi diesel fuel. The Iraqi diesel was emulsified using salt, sugar, and sodium carbonate as the emulsifying agent to produce water in oil emulsions. The emulsions fuel oil obtained were subjected for many tests to find out its thermophysical and combustion specifications and storage stability of the resulted emulsion to be used in the production of electric power, marine, bricks plants, and transportation.
\end{abstract}

Key words:

Keywords -Iraqi black oil, emulsifying agent, emulsions, fossil fuels.

\section{INTRODUCTION}

Marine and automotive transport, shipping and air transport account for nearly a third of the world's total energy consumption and contributes for more than $25 \%$ of the world's $\mathrm{CO}_{2}$, as well as methane and nitrogen oxides. The rest of the fossil fuels are used in the production of electric power, foundries and brick factories [1-3].

The escalating threats to global climate change have affected the policies of governments all over the world. The effects of climate change have caused major political and social reactions and have led to major shifts in social and economic policies. Climate change has always been on the agenda of political leaders of the European Union and the United Nations, governed by international agreements and scientific and political conferences have been held on this subject[5-7].

Global awareness of climate change has been on the increase and vigorous efforts have been made at the level of many new technologies to reduce greenhouse gas emissions and reduce their negative impact on the global economy and the health of present and future generations [8]. These efforts have increased to some extent in recent times to increase public awareness of the seriousness of climate change. These days, the world has begun to push for the use of alternative fuels such as bio-diesel and bio-ethanol as a substitute fuel for automotive engines and the marine industry [9-12]. Prior to this, several studies were conducted on the use of emulsified fuels to reduce the emission of polluting gases $\left(\mathrm{CO}_{2}, \mathrm{CO}, \mathrm{NOx}, \mathrm{SO}_{2}\right.$, etc.) to the environment $[13,14]$.

The emulsifier is a mixture of two liquids at the level of the droplet and the fluid joints are very overlapping. These systems have a minimum level of stability, which can be increased by adding an effective substance on the surface. This material may be solid in the form of molecules or liquids, known as surface agents, emulsifiers or emulsifiers $[15,16]$.

The possibility of combustion of emulsified fuel was examined to study the impact of this fuel on the performance of the engine and the resulting pollutants. Ref. [13] mixed diesel with water to form fuel emulsions and used it in some internal combustion engines. Ref. [17] has shown that certain factors enable two possible types of fuel oil emulsions: oil in water and water in oil emulsions.

From the previous literature review we find limited information on the stability of emulsion due to surfactant effect in emulsions due to the possession of both adsorption materials from emulsion (water and fuel) [18]. There are few studies on waterfront and heavy fuel [19].

The emulsifier is made up of water and fuel, and this material takes one of two forms: emulsifier fuel in water $(\mathrm{O} / \mathrm{W})$ that has oil inside the mole molecule. The emulsion of the water in the fuel $(\mathrm{W} / \mathrm{O})$ is where the oil is the outer part and the water inside. The emulsion system depends on the chemical nature of the emulsifying agents [20].

The stability of the emulsions used as fuel is of paramount importance, as the fuel emulsion must remain stable while kept in the mixing tank until it reaches the combustion chamber. The unstable emulsifier begins to detach before entering the combustion chamber [21]. 
The Iraqi diesel fuel is characterized by its moderate cetane number and high sulfur content. The Iraqi researchers worked hard to find alternatives to diesel fuel, as biodiesels, or by adding biodiesels and many other oxygenates to diesel [22-24]. Also, they tried to add gaseous fuels like hydrogen, Natural gas and liquefied petroleum gas to diesel and made the engine operates in duel fuel mode [25-33]

The aim of this study is to highlight some problems encountered in formulating water-in-oil (w/o) emulsions of diesel fuel: the nature and type of emulsifying agent, the method and means of mixing as well as the stability of the w/o emulsions. This work is a part of continuous efforts in Energy and Renewable Energies Technology Center, University of Technology, Baghdad, Iraq, to improve the Iraqi used fuels [34-79] and to work towards renewables for energy generations [80-109].

\section{MATERIALS AND METHODS}

Means of mixing: There are many types of emulsifying equipment available, including ultrasonic shakers, colloidal mills, high pressure conduits and mechanical mixers. In this study, an ultrasonic shaker type (TELSONIC ULTRASONICS CT-I2) was used. This shaker has a 12 liters tank and it is an appropriate mixer as it separates the liquid particles and mixes them with the existence of surfactant agent.

Select emulsifying factor: The real importance of the emulsion lies in deep changes in its compositionespecially at the double electrode layers near the interfaces. Double electrical layers control the emulsification stability by blocking particle coagulation. Emulsion effects are dispersed between the molecules of water and oil. Thus it makes it possible for water and oil to become thoroughly dispersed in each other, creating a homogeneous stable, smooth emulsion.

Emulsion Addiction: For a stable emulsion, you can use any of the following methods:

Method of agent in water: Emulsion is dissolved in water in the first stage and oil is then added with appropriate agitation.

Agent-in-oil method: This process is the reverse of agent in water method and it is used to produce w/o emulsion directly.

Nascent soap method: In is process soaps are used for as emulsions stabilizers.

Alternate addition method: Both water and oil is added alternatively.

In this study, the agent-in-oil method is used to produce the w/o emulsions.

Time of agitation: Under normal circumstances the average particle size decreases rapidly at first and then gradually reaches the limit value in 1-5 minutes. To ensure a homogeneous and stable emulsion, the ultrasonic vibration was maintained for 4 continuous hours per sample. After the mixing process, leave the sample to stabilize and observe the separation between water and oil daily to determine the duration of the emulsifier stability and the acceptable length of storage.

Experimental procedure:

Emulsion preparation: Different percentages of diesel in water mixtures adequately stabilized with several types of surfactants. In this study the aim was to find a popular and cheap surfactant that does not increase the cost of the produced fuel. For this purpose salt, sugar, sodium carbonates were used as surfactant by weight fractions of $0.1,0.2,0.3,0.4$, and 0.5 . The water was poured in the ultrasonic shaker and then the surfactant was left to dissolve in it and then the diesel fuel was added gradually. The shaker was left for 4 hours to confirm the complete the mixing. After the end of shaking process, a sample is taken from the produced emulsion and was kept for observation every day to define the time of separation. The percentage of water added to diesel was determined by $20 \%$ of the distilled water and was used to eliminate the number of experiments.

The used equipment

As mentioned before an ultrasonic shaker type (TELSONIC ULTRASONICS CT-I2) was used to prepare the emulsion duel. Emulsion density was measured using a sample $(250 \mathrm{ml})$ of the emulsifier fuel by weighting it and then divided by volume. The emulsion viscosity was measured using the Brookfield Programmer's viscometer (model: LVDV-III ultra-programmable) to gauge the viscosity of the produced fuel. The viscosity device is connected to a laptop computer to collect and storage data. Components of fuel as carbon, hydrogen, oxygen, sulfur, and nitrogen were examined at the laboratories of the Al-Doura Refinery in Baghdad, Iraq.

\section{RESULTS AND DISCUSSION}

Effect of the emulsifying agent: The choice of emulsifier factor is very important because it determines the stability of the resulting emulsifier as the combustion will be very difficult if the liquid is separated from each other during the combustion process, if not impossible, the flame cannot be maintained in the combustion chamber if the water surrounding the oil drops is separated and will work on Rapidly extinguish flame.

After obtaining a suitable agent, it is necessary to empirically determine the appropriate amount of it to be added. In this study, due to the use of more than one agent, so the beginning was with the smallest proportions to add and study the produced emulsion stability, so that the prevent mixture separating into the mixing tank for 
an acceptable time. The separation of the mixture means entering water into the combustion chamber, which causes the flame to extinguish and damage the fuel system.

On the other hand, the use of a very large amount of agent will cause confusion of the resulting emulsion, affect the spatially burning emulsion or may block the pump blades, thereby weakening the fuel propulsion into the combustion chamber.

Fig. 1 represents the effect of the used surfactant weight on the stability of the produced emulsions. The figure reveals that the highest stable emulsion was the one with salt $(0.4 \%$ weight fraction) where it continued stable for 32 days which is a suitable storage period of fuels to be used safely. Also, the other used agent gave good convergence in the days of stability where the $(0.5 \%)$ sodium carbonate continued stable for 22 days which is a good period. As well as, sugar with weight fraction of $0.3 \%$ continued stable for about 16 days. The low stability time of sugar can be referred to its nature as carbohydrate materials similar to the diesel fuel which makes it has lower effect then the other two materials which has sodium in its composition that may be the reason for the longer stability period. These three emulsions were selected to further tests to find its thermophysical and combustion properties.

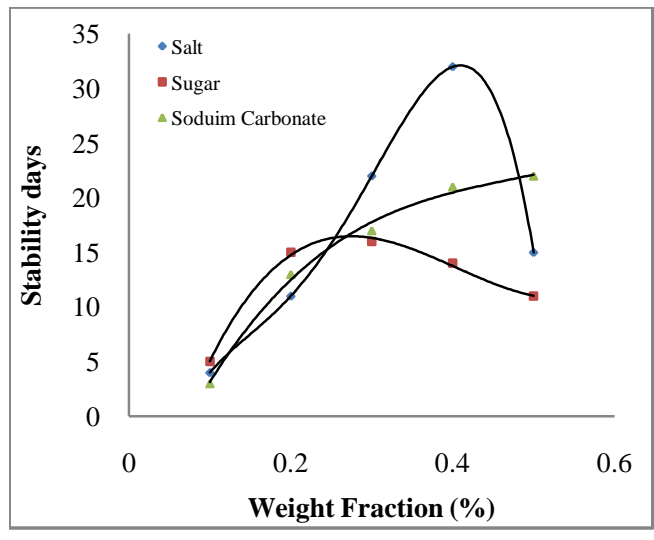

Fig. 1 Stability days for the produced emulsions

Table 1 illustrates the thermophysical and burning properties for three selected emulsions. These chosen emulsions were the three ones that have given the maximum stability as the former figure manifests. The main thermophysical property was the density. Density is the degree of compactness of a substance; also, it is a measure of the amount of information on a storage medium. If the density of the emulsion was increased greatly then the change of the fuel pump becomes a must. The table's results reveal low variation in the density of the emulsion does not exceed in the worst cases (salt and sodium carbonate emulsions) $2.43 \%$. This result means that the prepared emulsions are ready for use without the need for any improvement in the fuel system.

Table 1 Thermophysical and combustion properties of the selected emulsions compared with diesel fuel

\begin{tabular}{|l|c|c|c|c|}
\hline \multicolumn{1}{|c|}{ Property } & Diesel & $\begin{array}{c}\text { Salt emulsion } \\
(0.4 \%)\end{array}$ & $\begin{array}{c}\text { Sugar emulsion } \\
(0.3 \%)\end{array}$ & $\begin{array}{c}\text { Sodium carbonates } \\
(0.5 \%)\end{array}$ \\
\hline Density $\left(\mathrm{kg} / \mathrm{m}^{3}\right)$ & 820 & 840 & 835 & 840 \\
\hline Cetane number & 48.5 & 46.7 & 46.55 & 46.5 \\
\hline $\begin{array}{l}\text { Lower heating value } \\
(\mathrm{MJ} / \mathrm{kg})\end{array}$ & 42.31 & 43.76 & 43.45 & 43.7 \\
\hline Viscosity (cSt) & 2.87 & 2.99 & 3.0 & 2.98 \\
\hline Final boiling point $\left({ }^{\circ} \mathrm{C}\right)$ & 369.8 & 343.2 & 343.7 \\
\hline \multicolumn{5}{|c|}{ Element analysis } \\
\hline $\mathrm{C} \% \quad(\mathrm{w} / \mathrm{w})$ & 86 & 75 & 735 & 75 \\
\hline $\mathrm{H} \% \quad(\mathrm{w} / \mathrm{w})$ & 12.935 & 17.3 & 16.81 & 7.3 \\
\hline $\mathrm{O} \% \quad(\mathrm{w} / \mathrm{w})$ & - & 7 & 6.7 & 0.942 \\
\hline $\mathrm{S} \% \quad(\mathrm{w} / \mathrm{w})$ & 1 & 0.642 & 0.642 & 0.59 \\
\hline N\% (w/w) & 0.065 & 0.058 & 0.06 & 192 \\
\hline $\begin{array}{l}\text { Molecular weight } \\
(\mathrm{g} / \mathrm{mole})\end{array}$ & 211 & 191 & 193 & \\
\hline
\end{tabular}


The viscosity is another important thermophysical property that defines the state of being thick, sticky, and semi-fluid in consistency, due to internal friction. It is the real expression of the quantity that expresses the value of internal friction in any fluid; it is a measure of a fluid's resistance to flow. Viscosity describes the internal friction of moving liquids. A fluid with large viscosity resists motion because its molecular structure gives it a lot of internal friction. The liquid with low viscosity is easily flowing because the molecular structure has very little friction when in motion. Table 1 results reveal an increase in the three studied emulsion viscosities due to the water addition which has higher viscosity than diesel fuel. However the increase rate was 4.1, 4.5, and $3.83 \%$ for salt, sugar, and sodium carbonate emulsions, respectively. The little variations between the increase rates are caused by the surfactant used.

The ignition quality of diesel fuel is measured by the cetane number which is a quantity indicating the ignition properties of diesel fuel relative to cetane as a standard. If the diesel has a higher cetane umber that is mean it is easier to start a diesel engine. The cetane number indicates the proportion (volumetric fraction) of the cetane (chemical name hexadecane) in a combustible mixture (containing cetane and 1-methylanapthalene) that matches the ignition characteristics of the tested diesel fuel. The Iraqi diesel fuel has moderate cetane number ranges from 42 to 48 . This value reduced by adding water but its reduction was limited as $3.7,4.4$, and $4.5 \%$ for salt, sugar, and sodium carbonate emulsions, respectively. The tiny variations in reduction rates referred to the surfactant material.

The heating value of any fuel is the energy released per unit mass or per unit volume of fuel when the fuel is burned completely. Low heating value (LHV) for any fuel is defined as the net thermal value and is determined by subtracting the evaporation temperature of water vapor generated during fuel combustion from the higher heating value. In other words, the water vapor produced by combustion draws some of the heat from fuel combustion. The numerical difference between the LHV and the fuel HHV is roughly equivalent to the amount of heat evaporative potential that can be recovered practically in the secondary condenser per unit of burned fuel.

The LHV for the tested emulsion were increased slightly due to increase in the fuel's water content. The increment rates were 3.4, 2.7, and 3.28\% for salt, sugar, and sodium carbonate emulsions, respectively. Again, the small variations in the LHV changes are due to the used surfactant material.

The table shows that there are reductions in the final boiling points of the emulsions compared with diesel fuel due to the addition of water that have lower boiling point. The drop in the boiling point of the three emulsifiers was obvious; it was $7.2,6.7$, and $7 \%$ for salt, sugar, and sodium carbonate emulsions, respectively.

One of the most important consequences of adding water to diesel fuel is the low carbon-to-hydrogen ratio, which means high flame speed and temperature.Also, the high proportion of oxygen in the emulsion relative to the nonexistence in the original diesel, which means that the combustion will be complete and there will be reduction in the unburnt exhaust pollutants. However, there is another aspect of the image, providing oxygen and increasing the speed of combustion and temperatures because of the increase of the ratio of hydrogen to carbon means the high NOx pollutants resulting from combustion. As a result, there will be a good enhancement to burning quality with using the tested emulsions compared to diesel fuel alone.

\section{CONCLUSION}

Preparation of stable emulsions presented a lot of problems. It requires an emulsifying agent to produce stable distillate fuel emulsions (diesel is a distillate fuel). The choice of emulsifying agent is very important as a w/o or $\mathrm{o} / \mathrm{w}$ emulsion can be obtained, depending on the chemical nature of the agent. Successful combustion of fuels emulsified with water can only be achieved if the emulsion is of the water-in-oil (w/o) type. The limit on the percentage water content of an emulsion for effective and controllable combustion depends on the chemical nature of the emulsifying agent (which must be of the w/o type or a lipophilic) and the mixing device employed. Water-in-oil emulsions would have been welcomed as shipping companies would have embraced a fuel with higher combustion efficiency. But with the present trend of global events, interest is directed to operations that are rather environmentally friendly in terms of low pollutant emissions.

\section{REFERENCES}

[1] M T Chaichan\&A. M. Salih, Study of compression ignition engine performance when fueled with mixtures of diesel fuel and alcohols, Association of Arab Universities Journal of Engineering Science, 17(1), 2010, 1-22.

[2] M T Chaichan\&D. S. Al Zubaidi, Practical study of performance and emissions of diesel engine using biodiesel fuels, Association of Arab Universities Journal of Engineering Science, 18(1), 2012, 43-56.

[3] H M Al-Maamary, H. A.Kazem, M. T. Chaichan, Changing the energy profile of the GCC States: A review, International Journal of Applied Engineering Research (IJAER), 11(3), 2016, 1980-1988.

[4] H M Al-Maamary, H. A.Kazem, M. T. Chaichan, Renewable energy and GCC States energy challenges in the 21st century: A review, International Journal of Computation and Applied Sciences IJOCAAS, 2(1), 2017, 11-18. 
[5] H M Al-Maamary, H. A.Kazem, M. T.Chaichan, Climate change: the game changer in the GCC region, Renewable and Sustainable Energy Reviews, 76, 2017, 555-576.

http://dx.doi.org/10.1016/j.rser.2017.03.048

[6] H M Al-Maamary, H. A.Kazem, M. T. Chaichan, The impact of the oil price fluctuations on common renewable energies in GCC countries, Renewable and Sustainable Energy Reviews, 75, 2017, 989-1007.

[7] M T Chaichan, H. A.Kazem, T. A. Abid, The Environmental Impact of Transportation in Baghdad, Iraq, Environment, Development and Sustainability, 2016. DOI: 10.1007/s10668-016-9900-x.

[8] M T Chaichan, Emissions and Performance Characteristics of Ethanol-Diesel Blends in CI Engines, Engineering and Technology J, 28(21), pp: 6365-6383, 2010.

[9] M T Chaichan\&K. I. Abaas, Emissions Characteristics of Methanol-Diesel Blends in CI Engines, Wassit Journal for Science \& Medicine, 5(1), 2012, 177-189.

[10] S T Ahmed \&M. T.Chaichan, Effect of fuel cetane number on multi-cylinders direct injection diesel engine performance and emissions, Al-Khwarizmi Eng. Journal, 8(1), 2012, 65-75.

[11] M T Chaichan\&S. T. Ahmed, Evaluation of performance and emissions characteristics for compression ignition engine operated with disposal yellow grease, International Journal of Engineering and Science, 2(2), 2013, 111-122.

[12] M T Chaichan, Practical investigation of the performance and emission characteristics of DI compression ignition engine using water diesel emulsion as fuel, Al-Rafidain Engineering Journal, 21(4), 2013, 29-41.

[13] AMG Elshafie and S.K. Khalid, QSPR for HLB of non-ionic surfactant based polyoxyethylene group,J. Dispersion Sci. Technol., 29,2008, 940-947.

[14] P Baskar, A. S.Kumar, Experimental investigation on performance characteristics of a diesel engine using diesel-water emulsion with oxygen enriched air, Alexandria Engineering Journal, 56(1), 2017, 137-146.

[15] A R Al-Hashmi, T. K.Al-Wahaibi, Y. M.Al-Wahaibi, F. Mjalli, R. Al-Omairi, Transportation of heavy oils using polymerstabilized oil-in-water emulsions, J Petrol Explor Prod Technol, DOI 10.1007/s13202-016-0298-7, 2016.

[16] N Yusuf, Y. Al-Wahaibi, T. Al-Wahaibi, A. Al-Ajmi, A. S. Olawale, I. A. Mohammed, Effect of oil viscosity on the flow structure and pressure gradient in horizontal oil-water flow, Chem. Eng. Res. Des., 90, 2012, 1019-1030.

[17] N. Kumar, A. Sharma, V. Vibhanshu, Performance Analyses of Diesel Engine at Different Injection Angles Using Water Diesel Emulsion, SAE paper No. 2013-01-2170, 2013

[18] T. Murayama, M. Tsukahara, Y. Morishima, N. Miyamoto, Experimental Reduction of NOx, Smoke, and BSFC in a Diesel Engine Using Uniquely Produced Water (0 - 80\%) to Fuel Emulsion, SAE Technical Paper 780224, 1978, doi:10.4271/780224.

[19] D Hountalas, G. Mavropoulos, T. Zannis, Comparative Evaluation of EGR, Intake Water Injection and Fuel/Water Emulsion as NOx Reduction Techniques for Heavy Duty Diesel Engines, SAE Technical Paper No. 2007-01-0120, 2007, doi:10.4271/2007-010120.

[20] M T Chaichan, Performance and emission study of diesel engine using sunflowers oil-based biodiesel fuels, International Journal of Scientific and Engineering Research, 6(4), 2015, 260-269.

[21] M T Chaichan, Evaluation of emitted particulate matters emissions in multi-cylinder diesel engine fuelled with biodiesel, American Journal of Mechanical Engineering, 4(1), 2016, 1-6. (DOI: 10.12691/ajme-4-1-1)

[22] M T Chaichan, Practical measurements of laminar burning velocities and Markstein Numbers for Iraqi diesel-oxygenates blends, The Iraqi Journal for Mechanical and Material Engineering, 13(2), 2013, 289-306.

[23] M T Chaichan, Exhaust Analysis and Performance of a Single Cylinder Diesel Engine Run on Dual Fuels Mode, Baghdad Engineering Collage Journal, 17(4), 2011, 873-885.

[24] M T Chaichanand A. M. Salih, Practical investigation of performance of single cylinder compression ignition engine fueled with duel fuel, The Iraqi Journal for Mechanical and Material Engineering, 13(2), 2013, 198-211.

[25] M T Chaichan,D. S. Al-Zubaidi, A practical study of using hydrogen in dual - fuel compression ignition engine, International Journal of Mechanical Engineering (IIJME),.2(11), 2014, 1-10.

[26] M T Chaichan, Combustion of dual fuel type natural gas/liquid diesel fuel in compression ignition engine, Journal of Mechanical and Civil Engineering (IOSR JMCE), 11(6), 2014, 48-58

[27] M T Chaichan, D. S. Al-Zubaidi, Operational parameters influence on resulted noise of multi-cylinders engine runs on dual fuels mode, Journal of Al-Rafidain University Collage for Science, 35, 2014, 186-204.

[28] M T Chaichan, The Effects of Hydrogen Addition to Diesel Fuel on the Emitted Particulate Matters, International Journal of Scientific \& Engineering Research, 6(6), 2015, 1081-1087.

[29] M T Chaichan, Improvement of NOx-PM trade-off in CIE though blends of ethanol or methanol and EGR, International Advanced Research Journal in Science, Engineering and Technology, 2(12), 2015, 121-128. (DOI: 10.17148/IARJSET.2015.21222)

[30] M T Chaichan, Q. A. Abass, Effect of cool and hot EGR on performance of multi-cylinder CIE fueled with blends of diesel and methanol, Al-Nahrain Collage of Engineering Journal, 19(1), 2016, 76-85.

[31] M T Chaichan, Study of performance of SIE fueled with Supplementary hydrogen to gasoline, Baghdad Engineering Collage Journal,12(4), 2006, 983-996.

[32] M T Chaichan, Study of NOx and CO emissions for SIE fueled with Supplementary methane to LPG, The Iraqi Journal for Mechanical and Material Engineering, 6(2), 2006, 85-97.

[33] M T Chaichan, Study of NOx and CO emissions for SIE fueled with different kinds of hydrocarbon fuels,Association of Arab Universities Journal of Engineering Science, 13(2), 2006, 85-105.

[34] M T Chaichan, Study of performance of SIE fueled with Supplementary methane to LPG, The Iraqi Journal for Mechanical and Material Engineering ,7(4), 2007, 25-44.

[35] M T Chaichan, Study of performance of SIE fueled with different kinds of hydrocarbon fuels, Association of Arab Universities Journal of Engineering Science, 14(1), 2007, 25-44.

[36] M T Chaichan, Study of performance of SIE fueled with Supplementary hydrogen to LPG, Association of Arab Universities Journal of Engineering Science, 16(1), 2009, 125-145.

[37] M T Chaichan, Study of NOx and CO emissions for SIE fueled with Supplementary hydrogen to LPG, Association of Arab Universities Journal of Engineering Science, 16(2), 2009, 32-47.

[38] K I Abaas\&M. T.Chaichan, Experimental study of using solar energy storage wall for heating Iraqi houses purposes, Wassit Journal for Science \& Medicine, 2(2), 2009, 212-221.

[39] M T Chaichan, Study of NOx and CO emissions for SIE fueled with Supplementary hydrogen to gasoline, Baghdad Engineering Collage Journal, 16(1), 2010, 4606-4617.

[40] M T Chaichan, Practical measurements of laminar burning velocities for hydrogen-air mixtures using thermocouples, Association of Arab Universities Journal of Engineering Science, 17(2), 2010, 12-19. 
[41] M T Chaichanand A. M. Salih, Practical investigation of single cylinder SI Engine performance operated with various hydrocarbon fuels and hydrogen, Al Mostaseria Journal for engineering and development, 14(2), 2010, 183-197.

[42] M T Chaichanand K. I. Abaas, Experimental comparison of CO emissions emitted from single cylinder S I engine fueled with different kinds of hydrocarbon fuels and hydrogen, Iraqi Journal for Mechanical and Material Eng., 10(3), 2010, $397-405$.

[43] M T Chaichan\&H. A.Kazem, Thermal storage comparison for variable basement kinds of a solar chimney prototype in Baghdad Iraq weathers, International journal of Applied Science (IJAS), 2(2), 2011, 12-20.

[44] M T Chaichan, Practical study of basement kind effect on solar chimney air temperature in Baghdad-Iraq weather,Al Khwarizmi Eng. Journal, 7(1), 2011, 30-38.

[45] S. T. Ahmed \&M T Chaichan, A study of free convection in a solar chimney sample, Engineering and Technology J, 29(14), 2011, 2986-2997.

[46] M T Chaichan, Characterization of lean misfire limits of alternative gaseous fuels used for spark ignition engines, Tikrit Journal of Engineering Sciences, 19(1), 2012, 50-61.

[47] M T Chaichan\&A. M. Salih, Practical investigation of the effect of EGR on DI multi cylinders diesel engine emissions, Anbar Journal for Engineering Science (AJES), 6(3), 2013, 401-410.

[48] M T Chaichan, Measurements of laminar burning velocities and Markstein length for LPG-hydrogen-air mixtures, International Journal of Engineering Research and Development, 9(3), 2013, 22-30.

[49] M T Chaichan, The measurement of laminar burning velocities and Markstein numbers for hydrogen enriched natural gas, International Journal of Mechanical Engineering \& Technology (IJMET), 4(6), 2013, 110-121.

[50] A AAl-Waeely, S. D. Salman, W. Abdol-Reza, M. T.Chaichan, H. A.Kazemand H. Al-Jibori, Evaluation of the spatial distribution of shared electrical generators and their environmental effects at Al-Sader City-Baghdad-Iraq, International Journal of Engineering \& Technology IJET-IJENS, 14(2), 2014, 16-23.

[51] M T Chaichan, K. I. Abaas\&H. M. Salih, Practical investigation for water solar thermal storage system enhancement using sensible and latent heats in Baghdad-Iraq weathers, Journal of Al-Rafidain University Collage for Science, 33, 2014, 158-182.

[52] M T Chaichan, EGR effect on performance of a spark ignition engine fueled with blend of methanol-gasoline, Wassit Journal of Engineering Science, 1(2), 2013, 93-110.

[53] M T Chaichan, Experimental evaluation of the effect of some engine variables on emitted PM and Pb for single cylinder SIE, Association of Arab Universities Journal of Engineering Science, 2(20), 2013, 1-13.

[54]M T Chaichan, K. I. Abaas\&A. H. Naser, Study of the effect of exhaust gas recirculation on performance and emitted noise of an engine fueled with diesel fuel, Association of Arab Universities Journal of Engineering Science, 20(1), 2013, 43-59.

[55] M T Chaichan, Evaluation of the effect of cooled EGR on knock of SI engine fueled with alternative gaseous fuels, Sulaimani Journal for Engineering Science, 1(1), 2014, 7-15.

[56] M T Chaichan, Combustion and Emissions Characteristics for DI Diesel Engine Run by Partially-Premixed (PPCI) Low Temperature Combustion (LTC) Mode, International Journal of Mechanical Engineering (IIJME), 2(10), 2014, 7-16.

[57]A M Salih\&M. T.Chaichan, The effect of initial pressure and temperature upon the laminar burning velocity and flame stability for propane-air mixtures, Global Advanced Research Journal of Engineering, Technology and Innovation, 3(7), $2014,154-201$.

[58] M T Chaichan, A. Q. Salam \&S. Abdul-Aziz, Impact of EGR on engine performance and emissions for CIE fueled with dieselethanol blends, Association of Arab Universities Journal of Engineering Science, 27(2), 2014, 21-28.

[59] M T Chaichan, Exhaust gas recirculation (EGR) and injection timing effect on emitted emissions at idle period, Al-Khwarizmi Engineering Journal, Al-Khwarizmi Engineering Journal,10(4), 2014, 33-44.

[60] M T Chaichan,K. I. Abaas, EGR and Injection Timing Variation Effects of an Engine Run in HCCI Mode Performance and Emitted Emissions, International Journal of Engineering Trends and Technology (IJETT), 19(3), 2015, 120-130.

[61] M T Chaichan, The impact of equivalence ratio on performance and emissions of a hydrogen-diesel dual fuel engine with cooled exhaust gas recirculation, International Journal of Scientific \& Engineering Research, 6(6), 2015, 938-941.

[62]S H Khudhur, A. M. Salih, M. T.Chaichan, The Effect of Variable Valve Timing on SIE Performance and Emissions, International Journal of Scientific \& Engineering Research, 6(8), 2015, 173-179.

[63] M T Chaichan, The impact of engine operating variables on emitted PM and $\mathrm{Pb}$ for an SIE fueled with variable ethanol-Iraqi gasoline blends, IOSR Journal of Mechanical and Civil Engineering (IOSRJMCE), 12(6-1), 2015, 72-79.

[64] M T Chaichan, EGR effects on hydrogen engines performance and emissions, International Journal of Scientific \& Engineering Research, 7(3), 2016, 80-90.

[65]M T Chaichan, O. Maroon, K. I. Abaas, The effect of diesel engine cold start period on the emittedemissions, International Journal of Scientific \& Engineering Research, 7(3), 2016, 749-753.

[66] M T Chaichan, Effect of injection timing and coolant temperatures of DI diesel engine on cold and hot engine startability and emissions, IOSR Journal of Mechanical and Civil Engineering (IOSRJMCE), 13(3-6), 2016, 62-70.

[67] M T Chaichan, Spark ignition engine performance fueled with hydrogen enriched liquefied petroleum gas (LPG),Scholars Bulletin Journal, 2(9), 537-546, 2016.

[58] M T Chaichan, GEM Ternary Blends utilization as an alternative to conventional Iraqi gasoline to suppress emitted sulfur and lead components to environment, Al-Khwarizmi Journal, 12(3), 2016, 38-51.

[69] M T Chaichan, J. A. Kadhum, K. S. Riza, Spark Ignition Engine Performance When Fueled with NG, LPG and Gasoline, Saudi Journal of Engineering and Technology, 1(3), 2016, 105-116. DOI: 10.21276/sjeat.2016.1.3.7

[70] M T Chaichan, O. Marhoon, B. A. Mohammed, The effect of spark ignition engine cold starting period on the emitted emissions, Scientific and Eng. Reports, 1(1), 2016, 1-8. DOI: 10.18282/ser.v1.i1.40

[71] M T Chaichan, N. M. Ali, Experimental investigation of the effect of exhausts gas recirculation (EGR) on NOx-Smoke trade-off for SIE fueled with blends of gasoline/bioethanol, Al-Rafidain Collage Journal, 39, 2016, pp. 388-404.

[72] M T Chaichan, K. I. Abaas, B. A. Mohammed, Experimental Study of the Effect of fuel type on the Emitted Emissions from SIE at Idle Period, Al-Khwarizmi Engineering Journal,13(1), 2017, 1-12.

[73] M T Chaichan\&K. I. Abaas, Practical investigation for improving concentrating solar power stations efficiency in Iraqi weathers, Anbar J for Engineering Science, 5(1), 2012, 76-87.

[74] H A Kazem, M. T.Chaichan, I. Al-Shezawi, H. Al-Saidi, H. Al-Rubkhi, J. Al-Sinani and A. Al-Waeli, Effect of Humidity on the PV Performance in Oman, Asian Transactions on Engineering , 2(4), 2012, 29-32.

[75] M T Chaichan\&K. I. Abaas,Productivity amelioration of solar water distillator linked with salt gradient pond,Tikrit Journal of Engineering Sciences, 19(4), 2012, 24-34.

[76] M T Chaichan, K. I. Abaas, H. A.Kazem, Al Jibori H S \& Abdul Hussain U, Novel design of solar receiver in concentrated power system, International J. of Multidispl. Research \&Advcs.in Eng. (IJMRAE), 5(1), 2013, 211-226. 
[77]S Faris, M. T.Chaichan, M Sachit and J. Jaleel, Simulation and numerical investigation of effect air gap thickness on Trombe wall system, International Journal of Application or Innovation in Engineering \& Management (IJAIEM), 3(11), 2014, $159-168$.

[78] M T Chaichan\&S. Faris, Practical investigation of the environmental hazards of idle time and speed of compression ignition engine fueled with Iraqi diesel fuel, International J for Mechanical and Civil Eng., 12(1), 2015, 29-34.

[79] M T Chaichan\&H. A.Kazem, Using aluminum powder with PCM (paraffin wax) to enhance single slope solar water distillator productivity in Baghdad-Iraq winter weathers, International Journal of Renewable Energy Research, 1(5), 2015, 151-159.

[80] M T Chaichan, K. I. Abaas, Performance amelioration of a Trombe wall by using phase change material (PCM), International Advanced Research Journal in Science, Engineering and Technology, 2(4), 2015, 1-6.

[81] M T Chaichan\&H. A.Kazem, Water solar distiller productivity enhancement using concentrating solar water heater and phase change material (PCM), Case Studies in Thermal Engineering, Elsevier, 5,pp: 151-159, 2015.

[82] M T Chaichan, H. A.Kazem, A. Kazem, K. I. Abaas, K. Al-Asadi, The effect of environmental conditions on concentrated solar system in desertec weathers, International Journal of Scientific and Engineering Research, 6(5), 2015, 850-856.

[83] M T Chaichan andK. Al-Asadi, Environmental Impact Assessment of traffic in Oman, International Journal of Scientific \& Engineering Research, 6(7), 2015, 493-496.

[84] M T Chaichan, D. S. Al-Zubaidi, Control of hydraulic transients in the water piping system in Badra-pumping station No.5, AlNahrain University, College of Engineering Journal (NUCEJ), 18(2), 2015, 229-239.

[85] T Chaichan,K. I. Abaas, H. A.Kazem, Design and assessment of solar concentrator distillating system using phase change materials (PCM) suitable for desertec weathers, Desalination and water treatment, 57(32), 2016, 14897-14907. DOI: 10.1080/19443994.2015.1069221

[86] H A Kazem, A. Al-Waeli, A. Al-Mamari, A. Al-Kabi, M. T.Chaichan, A photovoltaic application in car parking lights with recycled batteries: A techno-economic study, Australian Journal of Basic and Applied Science, 9(36), 2015, 43-49.

[87] H A Kazem, M. T.Chaichan, Experimental analysis of the performance characteristics of PEM Fuel Cells, International Journal of Scientific \& Engineering Research, 7(2), 2016, 49-56.

[88] H A Kazem, A. Al-Waeli, M. T.Chaichan, A. Al-Mamari, A. Al-Kabi, Design, measurement and evaluation of photovoltaic pumping system for rural areas in Oman, Environmental Development and Sustainability, 2016. DOI 10.1007/s10668-016-9773-z.

[89] M T Chaichan, H. A.Kazem, Experimental analysis of solar intensity on photovoltaic in hot and humid weather conditions, International Journal of Scientific \& Engineering Research, 7(3), 2016, 91-96.

[90] M T Chaichan, A. Al-Hamdani, A.M. Kasem, Enhancing a Trombe wall charging and discharging processes by adding nano- $\mathrm{Al}_{2} \mathrm{O}_{3}$ to phase change materials, International Journal of Scientific \& Engineering Research, 7(3), 2016, 736-741.

[91] M T Chaichan, Enhancing productivity of concentrating solar distillating system accompanied with PCM at hot climate, Wulevina 23(5), pp: 1-18, 2016.

[92] M T Chaichan, H. A.Kazem, K. I. Abaas, A. Al- Waeli, Homemade Solar Desalination System for Omani families,International Journal of Scientific \& Engineering Research, 7(5), 2016, 1499-1504.

[93] H A Kazem,H. Al-Badi,A. Al Busaidi\&M. T.Chaichan, Optimum design and evaluation of hybrid solar/wind/diesel power system for Masirah Island, Environment, Development and Sustainability, 2016. DOI: 10.1007/s10668-016-9828-1

[94] M T Chaichan, K. I. Abaas, D. S. Al-Zubidi, A study of a hybrid solar heat storage wall (Trombe wall) utilizing paraffin wax and water, Journal of Research in Mechanical Engineering, 2(11), 2016, 1-7.

[95] M T Chaichan, K. I. Abaas, D. S. Al-Zubidi, H. A.Kazem, Practical investigation of effectiveness of direct solar-powered air heater, International Journal of Advanced Engineering, Management and Science (IJAEMS), 2(7), 2016, 1047-1053.

[96] H A Kazem, A. Al-Waeli, M. T.Chaichan, A. Al-Mamari, A. Al-Kabi, Design, measurement and evaluation of photovoltaic pumping system for rural areas in Oman, Environment, Development and Sustainability, DOI: 10.1007/s10668-016-9773-z, 2016.

[97] H A Kazemand M. T.Chaichan,The impact of using solar colored filters to cover the PV panel on its outcomes, Bulletin Journal, 2(7), 464-469, 2016. DOI: 10.21276/sb.2016.2.7.5.

[98] A H Al-Waeli, H. A.Kazem, M. T.Chaichan, Review and design of a standalone PV system performance, International Journal of Computation and Applied Sciences IJOCAAS, 1(1), 2016, 1-6.

[99] H A Kazem, M. T.Chaichan, Effect of Environmental Variables on Photovoltaic Performance-Based on Experimental Studies, International Journal of Civil, Mechanical and Energy Science (IJCMES), 2(4), 2016, 1-8.

[100] H AKazemand M. T.Chaichan, Experimental effect of dust physical properties on photovoltaic module in northern Oman, Solar Energy, 139, 2016, 68-80.

[101] H A Kazem, J. H. Yousif, M. T.Chaichan, Modeling of Daily Solar Energy System Prediction using Support Vector Machine for Oman, International Journal of Applied Engineering Research, 11(20), 2016, 10166-10172.

[102] R S Jawad, M. T.Chaichan, J. A. Kadhum,Nanoparticles (NPs) leverage in Lithium-Ion Batteries Performance, International Journal of Pharmacy \& Technology, 8(3), 2016, 18995-19004.

[103] A H Al-Waeli, K. Sopian, H. A.Kazemand M. T.Chaichan, Photovoltaic Solar Thermal (PV/T) Collectors Past, Present and Future: A Review, International Journal of Applied Engineering Research, 11(22), 2016, 1075-10765.

[104] M T Chaichan, K. I. Abaas, R. S. Jawad, A. M. Mahdy, Thermal performance enhancement of simple Trombe wall, International Journal of Computation and Applied Sciences IJOCAAS, 2(1), 2017, 33-40.

[105] M T Chaichan, H. A.Kazem, Effect of sand, ash and soil on photovoltaic performance: An experimental study, International Journal of Scientific Engineering and Science, 1(2), 2017, 27-32.

[106] A H Al-Waeli, M. El-Din, A. Al-Kabi, A. Al-Mamari, H. A.Kazem, and M. T.Chaichan, Optimum Design and Evaluation of Solar Water Pumping System for Rural Areas, International Journal of Renewable Energy Research, 7(1), 2017, 12-20.

[107] M T Chaichan, K. I. Abaas, B. A. Mohammed, Experimental Study of the Effect of fuel type on the Emitted Emissions from SIE at Idle Period, Al-Khwarizmi Engineering Journal, 13(1), 2017, 1-12.

[108] A H Al-Waeli, K. Sopian, M. T.Chaichan,H. A.Kazem, H. A. Hasan, A. Al-Shamani, An experimental investigation on using of nano-SiC-water as base-fluid for photovoltaic thermal system, Energy Conservation and Management, 142, pp. 547-558, 2017.

[109] A H Al-Waeli, K. Sopian, H. A. Kazem and M. T. Chaichan, Photovoltaic thermal PV/T systems: A review, International Journal of Computation and Applied Sciences IJOCAAS, 2(2), 2017, 62-67. 